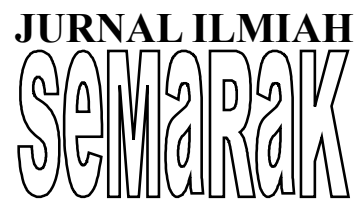

P-ISSN 2615-6849, E-ISSN 2622-3686

Jurnal Semarak,Vol. 2,No.2, Juni 2019, Hal (110- 123)

@ Prodi Manajemen Fakultas Ekonomi Universitas Pamulang

\title{
EVALUASI PROGRAM PELATIHAN DESAIN PEMBELAJARAN BAGI DOSEN UNIVERSITAS TERBUKA
}

\author{
Heri Saputra \\ Staf Pengajar Fakultas Ekonomi Universitas Pamulang \\ email: herisaputra@gmail.com
}

\begin{abstract}
ABSTRAK
Penelitian ini bertujuan untuk mengevaluasi hasil dari program pelatihan desain pembelajaran bagi dosen Universitas Terbuka. Program pelatihan ini dilakukan melalui proses belajar tatap muka 16 kali pertemuan setara 3 SKS dalam program pasca sarjana. Peserta menghasilkan produk atau porto folio desain matakuliah yang diampunya. Penelitian ini menggunakan pendekatan mixed method yang menganalisis hasil baik secara kualitatif maupun kuantitatif. Jenis penelitian yang dilakukan adalah penelitian evaluasi program dengan model CIPP (context, input, process, product). Evaluasi dilakukan dengan menilai keempat komponen tersebut dalam menyelenggarakan program pelatihan. Hasil penelitian menunjukkan komponen konteks sesuai dengan kebutuhan institusi dan peserta. Komponen input program pelatihan sudah cukup baik walaupun masih ada perbaikan. Penilaian komponen proses menunjukkan bahwa aktivitas belajar sesuai dengan kompetensi yang perlu dimiliki oleh peserta. Sedangkan penilaian produk menilai peserta menghasilkan produk desain pembelajaran yang memadai sesuai dengan kompetensi yang dihasilkan.
\end{abstract}

Kata kunci: evaluasi dan pelatihan

\section{ABSTRACT}

This study aims to evaluate the results of a learning design training program for Open University lecturers. This training program is carried out through face-to-face learning processes 16 times the equivalent of 3 credits in postgraduate programs. The participant produces a product or portfolio design course that he has chosen. This study uses a mixed method approach that analyzes results both qualitatively and quantitatively. The type of research conducted is program evaluation research with the CIPP model (context, input, process, product). Evaluation is carried out by assessing the four components in conducting a training program. The results of the study show the context component in accordance with the needs of the institution and the participants. The input component of the training program is quite good even though there are still improvements. Assessment of process components shows that learning activities are in accordance with the competencies that participants need to have. While the product assessment assesses the participants produce adequate learning design products in accordance with the competencies produced.

Keywords: evaluation and training.

\section{PENDAhUluan}

\section{A. Latar Belakang}

Universitas Terbuka

merupakan perguruan tinggi negeri (PTN)

yang menerapkan sistem belajar jarak jauh

(SBJJ). Dalam SBJJ mahasiswa

ditekankan belajar mandiri dengan

menggunakan media bahan ajar yang sengaja dirancang dan dikembangkan untuk SBJJ. UT menggunakan bahan ajar cetak dan non cetak untuk memfasilitasi proses belajar mahasiswa.

Sistem belajar jarak jauh (SBJJ) yang diterapkan UT menjadikan bahan ajar cetak dan non cetak sebagai bahan ajar utama yang dikembangkan secara khusus. Tujuan penggunaan bahan ajar 
adalah agar dapat digunakan dalam membantu mahasiswa untuk belajar mandiri dan mencapai kompetensi. Oleh karenanya, kualitas pembelajaran di UT sangat ditentukan oleh kualitas bahan ajarnya. Untuk mendukung keberhasilan mahasiswa dalam belajarnya, maka kualitas bahan ajar UT harus tetap dijaga dan ditingkatkan.

Bahan ajar UT harus mampu membawa mahasiswa mencapai dalam kompetensi yang diperlukan. Dalam hal ini kompetensi dapat diindikasikan dengan kinerja yang minimal baik sebagai hasil dari penggunaan kemampuan. Kemampuan itu sendiri adalah hasil penerapan dari kombinasi pengetahuan, keterampilan, dan sikap perilaku (Atwi Suparman, 2012:67).

Oleh karena itu bahan ajar UT harus didesain dengan baik agar bermutu. Desain dan pengembangan bahan ajar dilakukan baik oleh dosen UT sendiri dan dosen perguruan tinggi negeri (PTN) yang memenuhi persyaratan akademis yang telah ditentukan. Untuk dapat mendesain dan mengembangkan bahan ajar yang bermutu, efektif, efisien, dan menarik dosen UT perlu memiliki kemampuan dan keterampilan dalam mendesain dan mengembangkan bahan ajar. Kemampuan desain dan pengembangan bahan ajar dosen akan terakomodasi apabila telah memahami desain sistem instruksional. Desain sistem instruksional yaitu proses sitematik yang dilakukan dengan menterjemahkan prinsip-prinsip belajar dan pembelajaran menjadi rancangan yang dapat diimplementasikan dalam bahan dan aktivitas pembelajaran (Smith dan Ragan, 1993 dalam Benny A. Pribadi, 2009:58).

Program pelatihan desain pembelajaran ini adalah program pelatihan yang membahas suatu proses yang sistematik ke arah pengembangan bahan pembelajaran sehingga hasilnya dapat digunakan sebagai pegangan dalam melaksanakan pelatihan yang efektif dan efisien. Dalam proses tersebut terdapat berbagai langkah yang runtut mulai dari penentuan tujuan instruksional umum, analisis tujuan instruksional umum menjadi tujuan instruksional khusus dengan mempertimbangkan prilaku awal peserta didik, pembuatan tes acuan patokan, penyusunan strategi instruksional yang relevan untuk setiap tujuan instruksional khusus, pengembangan bahan instruksional, perancangan dan pelaksanaan evaluasi formatif, perevisian bahan instruksional berdasarkan hasil evaluasi formatif, sampai pada penggunaan bahan instruksional dan perancangan/pelaksanaan evaluasi sumatif.

Untuk meningkatkan kemampuan dosen UT dalam mendesain dan mengembangkan bahan ajar, UT dan Pusat Pengembangan Sumber Daya Manusia UT perlu menyelenggarakan Program Pelatihan Desain Pembelajaran bagi Dosen UT.

Untuk mengetahui efektivitas dan efisiensi penyelenggaraan program pelatihan desain pembelajaran maka perlu dilakukan evaluasi. Evaluasi bertujuan untuk mengetahui apakah program 


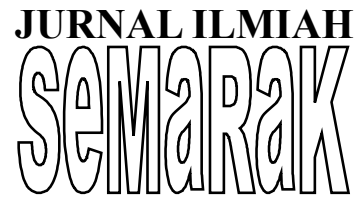

pelatihan desain pembelajaran mencapai sasaran yang diinginkan.

Menurut Stufflebeam yang di kutip oleh Ansyar (1989) bahwa evaluasi adalah proses memperoleh dan menyajikan informasi yang berguna untuk mempertimbangkan alternatif-alternatif pengambilan keputusan. Selanjutnya The joint committee on Standars For Educational Evaluation(1994), mendefinisikan bahwa evaluasi sebagai kegiatan investigasi yang sistematis tentang keberhasilan suatu tujuan.

Berdasarkan latar belakang di atas, maka penulis tertarik untuk mengambil judul penelitian "Evaluasi Program Pelatihan Desain Pembelajaran Bagi Dosen Universitas Terbuka".

\section{B. Perumusan Masalah}

Berdasarkan latar belakang yang telah diuraikan di atas, maka rumusan masalah yang diajukan dalam penelitian adalah seberapa besar efektivitas dan efisiensi Program Pelatihan Desain Instruksional bagi Dosen UT ?. Secara spesifik penelitian ini berfokus pada upaya untuk menjawab pertanyaan, yaitu:

1. Bagaimana relevansi/tujuan/landasan (konteks) penyelanggaraan program pelatihan desain pembelajaran bagi dosen UT?

2. Apakah kriteria peserta dan instruktur (input) sudah memadai ?

3. Bagaimana aktivitas proses pembelajaran (proses) pelatihan tersebut?

4. Apakah hasil produk pelatihan sudah mencapai sasaran ?

\section{Tujuan Penelitian}

Berdasarkan latar belakang masalah dan perumusan masalah, maka tujuan dalam penelitian ini adalah sebagai berikut:

1. Untuk mengetahui tujuan atau landasan (konteks) program pelatihan tersebut.

2. Untuk mengetahui kriteria peserta dan instruktur (input) sudah memadai.

3. Untuk mengetahui aktivitas proses pembelajaran (proses) pelatihan tersebut.

4. Untuk mengetahui produk hasil program pelatihan tersebut.

\section{TINJAUAN PUSTAKA}

\section{A. Manajemen Sumber Daya Manusia}

\section{Pengertian Manajemen}

Kata manajemen berasal dari bahasa Inggris yaitu "manage" yang berarti mengatur, mengelola, mengendalikan, mengusahakan, dan memimpin.

Menurut Malayu S. P. Hasibuan (2005:2) manajemen adalah ilmu dan seni mengatur proses pemanfaatan sumber daya manusia dan sumbersumber lainnya secara efektif dan efisien untuk mencapai suatu tujuan tertentu.

Jadi dapat disimpulkan bahwa manajemen adalah suatu proses yang terdiri dari rangkaian kegiatan seperti rencanaan, organisasi, pengembangan, pengendalian, dan pengawasan yang dilakukan untuk menentukan dan mencapai tujuan organisasi maupun 
tujuan individual secara efektif dan efisien.

\section{Pengertian Manajemen Sumber} Daya Manusia

Manajemen sumber daya manusia pada hakekatnya adalah penerapan manajemen, khususnya manajemen sumber daya manusia.

Pengertian manajemen sumber daya manusia menurut Fisher dan kawan kawan dalam Yun Iswanto (2009:1.18) manajemen sumber daya manusia meliputi keseluruhan keputusan dan praktik manajemen yang secara langsung berdampak atau mempengaruhi orang-orang yang bekerja untuk organisasi. Sedangkan keselurahan keputusan dan praktik manajemen meliputi: perencanaan sumber daya manusia dan analisis jabatan; masukan organisasional; pengembangan produktivitas sumber daya manusia; penilaian kinerja dan sistem penghargaan; dan menjaga agar sumber daya manusia tetap baik dan kerasan/betah bekerja dalam organisasi.

\section{Fungsi MSDM}

Fungsi manajemen sumber daya manusia menurut Malayu S.P. Hasibuan (2005: 21) adalah:
a. Perencanaan
b. Pengorganisasian
c. Pengarahan
d. Pengendalian
e. Pengadaan
f. Pengembangan

g. Kompensasi

h. Pengintegrasian

i. Pemeliharaan

j. Kedisiplinan

k. Pemberhentian

4. Tujuan Manajemen Sumber Daya Manusia

Tujuan manajemen sumber daya manusia adalah memperbaiki kontribusi produktif orang-orang atau tenaga kerja terhadap organisasi atau perusahaan dengan cara yang bertanggung jawab secara strategis, etis dan sosial. Para manajer dan departemen sumber daya manusia mencapai maksud mereka dengan memenuhi tujuannya.

\section{Sasaran Manajemen Sumber Daya} Manusia

Terkadang sasaran di pikirkan secara seksama dan diekspresikan dalam bentuk tulisan. Sering sasaran tidak dinyatakan secara formal. Tantangan ini menegaskan empat sasaran yang relatif umum bagi manajemen SDM dan membentuk sebuah kerangka masalah yang sering ditemui dalam perusahaan yaitu : sasaran perusahaan, sasaran fungsional, sasaran sosial, dan sasaran pribadi karyawan.

\section{B. Evaluasi Program Pelatihan}

\section{Pengertian Evaluasi}

Menurut Stufflebeam (2007, p. 326) dalam Atwi Suparman (2012: 301) mengemukakan "Evaluation is a systematic investigation of some object's value". Evaluasi adalah suatu 


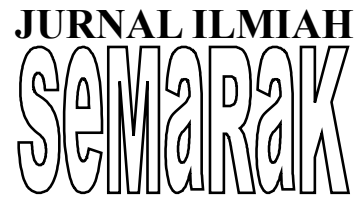

investigasi yang sistematik tentang nilai suatu obyek. Definisi ini bersifat konseptual dan umum sehingga perlu melihat definisi-definisi yang lain. Komisi Bersama Bidang Evaluasi mengemukakan bahwa evaluasi adalah penilaian yang sistematik tentang nilai, harga atau manfaat dari suatu obyek.

\section{Komponen Evaluasi Program Pelatihan}

Dalam evaluasi program pelatihan, ada banyak model yang dapat digunakan untuk mengevaluasi program. Meskipun antara satu dengan lainnya berbeda, namun maksudnya sama yaitu melakukan kegiatan pengumpulan data atau informasi yang berkenaan dengan objek yang dievaluasi, yang tujuannya menyediakan bahan bagi pengambil keputusan dalam menentukan tindak lanjut suatu program.

a. Context

Menurut Atwi Suparman (2012:303) evaluasi context (konteks) dimaksudkan untuk memvalidasi atau meningkatkan ketepatan tujuan umum dipandang dari kesesuainnya bagi pemecahan masalah. Dalam praktek proyek atau program instruksional, evaluasi konteks meliputi penilaian terhadap kebutuhan dan masalah instruksional, tujuan instruksional umum, sumber daya yang tersedia, dan kesempatan pelaksanaan program instruksional. b. Input

Menurut Stufflebeam dalam Rina Sukawati (2010:24) orientasi utama dari evaluasi input adalah untuk membantu menentukan suatu program untuk membuat perubahan yang diperlukan.

c. Process

Worthen \& Sanders (1981 : 137) dalam Eko Putro Widoyoko menjelaskan bahwa, evaluasi proses menekankan pada tiga tujuan : “ 1) do detect or predict in procedural design or its implementation during implementation stage, 2) to provide information for programmed decision, and 3) to maintain a record of the procedure as it occurs". Evaluasi proses digunakan untuk menditeksi atau memprediksi rancangan prosedur atau rancangan implementasi selama tahap dalam implementasi, dapat menyediakan informasi untuk keputusan program dan sebagai rekaman atau arsip prosedur yang telah terjadi.

d. Product

Menurut Atwi Suparman (2012:303) evaluasi product (produk) dimaksudkan untuk menilai hasil program yang meliputi pencapaian tujuan, ketidaktercapaian tujuan, dan efek samping baik yang positif maupun yang negatif.

\section{Pelatihan}

\section{Pengertian pelatihan}

Pelatihan (training) menurut Ambar Teguh Sulistiyani dan Rosidah 


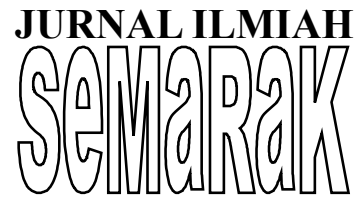

(2003:175) adalah proses sistematik pengubahan perilaku para pegawai dalam suatu arah guna meningkatkan tujuan-tujuan organisasional. Pelatihan penting karena pelatihan merupakan cara yang digunakan oleh organisasi untuk mempertahankan, menjaga, memelihara pegawai publik dalam organisasi dan sekaligus meningkatkan keahlian para pegawai untuk kemudian dapat meningkatkan produktivitasnya.

\section{Komponen-komponen Pelatihan}

Komponen-komponen menurut Anwar A.A. Prabu Mangkunegara, (2005:52) adalah:

a. Tujuan dan sasaran pelatihan dan pengembangan harus jelas dan dapat diukur.

b. Para pelatih harus ahlinya yang berkualifikasi dan harus memadai (professional).

c. Materi pelatihan harus disesuaikan dengan tujuan yang hendak dicapai.

d. Suatu metode pelatihan dan pengembangan harus disesuaikan dengan tingkat kemampuan pegawai yang menjadi peserta.

e. Peserta pelatihan dan pengembangan (trainers) harus mampu memenuhi persyaratan yang ditentukan.

\section{Manfaat Program Pelatihan}

Adapun manfaat pelatihan menurut Henry Simamora (2004:278) adalah sebagai berikut: mampu meningkatkan kuantitas dan kualitas produktivitas, mengurangi waktu belajar yang akan diperlukan karyanwan untuk mencapai standar kinerja yang dapat diterima, membentuk sikap loyalitas dan kerjasama yang lebih menguntungkan, memenuhi kebutuhan perencanaan sumber daya manusia, mengurangi frekuensi dan biaya kecelakaan kerja, untuk membantu karyawan dalam peningkatan dan pengembangan pribadi mereka.

\section{Tujuan Pelatihan}

Tujuan pelatihan menurut Anwar

A. A. Prabu Mangkunegara (2005:52) tujuan dari pelatihan adalah:

a. Meningkatan penghayatan jiwa dan ideologi.

b. Meningkatkan produktivitas kerja.

c. Meningkatkan kualitas kerja.

d. Untuk Meningkatkan ketetapan perencanaan sumber daya manusia.

e. Meningkatkan moral dan semangat kerja.

f. Meningkatkan rangsangan agar pegawai mampu berprestasi secara maksimal.

g. Untuk meningkatkan kesehatan dan keselamatan kerja.

h. Untuk menghindarkan keusangan (obsolescence).

i. Untuk meningkatkan perkembangan pribadi pegawai.

\section{Metode Pelatihan}

Metode latihan menurut Andrew F. Sikula dalam Anwar A.A. Prabu Mangkunegara, (2005:63) adalah on the job, vestibule, demonstrasi dan contoh, simulasi, apprenticeship, metode ruang kelas. Metode pelatihan 


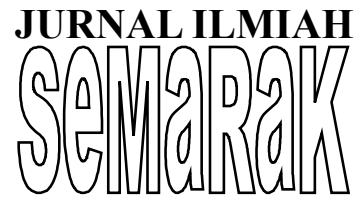

lainnya seperti metode seminar, kuliah, seminar, konferensi, kursus-kursus, dll.

\section{Desain Pembelajaran/Instruksional}

Menurut Atwi Suparman (2014:

138) Desain instruksional adalah suatu ilmu dan seni untuk menciptakan sistem istruksional berkualitas melalui proses analitik, sistematik, sistemik, efektif, dan efisien ke arah tercapainya hasil belajar yang sesuai dengan kebutuhan istruksional peserta didik.

\section{METODE PENELITIAN}

Menurut Sugiyono metodologi penelitian pada dasarnya merupakan cara ilmiah untuk mendapatkan data dengan tujuan dan kegunaan tertentu. Berdasarkan hal tersebut terdapat empat kata kunci yang perlu diperhatikan yaitu cara ilmiah, data, tujuan, dan kegunaan.

Tempat penelitian ini dilakukan di Universitas Terbuka jalan Cabe Raya, Tangerang Selatan. Objek penelitian atau sumber datanya adalah koordinator pelatihan PPSDM, instruktur program pelatihan desain pembelajaran, dan dosen yang mengikuti pelatihan.

Adapun waktu penelitian ini dilakukan selama tiga bulan, yaitu mulai bulan Januari sampai April 2014. Dalam penelitian ini diawali dengan observasi pendahuluan, penyusunan surat izin, pengumpulan data studi keperpustakaan, pembuatan proposal, konsultasi dengan dosen pembimbing, dan orang-orang yang berhubungan dengan penelitian ini.
Penelitian ini merupakan penelitian evaluasi yang berorientasi untuk melihat sejauhmana efektivitas dan efisiensi penyelenggaraan program pelatihan desain pembelajaran bagi dosen UT pada tahun 2012. penulis menggunakan jenis penelitian campuran (mixed methodology). Mixed method menghasilkan fakta yang lebih komprehensif dalam meneliti masalah penelitian, karena peneliti ini memiliki kebebasan untuk menggunakan semua alat pengumpul data sesuai dengan jenis data yang dibutuhkan. Sedangkan kuantitatif atau kualitatif hanya terbatas pada jenis alat pengumpul data tertentu saja.

Dasar kegiatan dalam evaluasi program pelatihan desain pembelajaran ini berfokus pada konteks, input, proses, dan produk. Orientasi mendasar pada penelitian ini adalah efektifitas dan efisiensi. Penelitian evaluasi ini dengan model CIPP bertujuan untuk memperbaiki, meningkatkan, dan memanfaatkan hasil penelitian.

CIPP memandang evaluasi sebagai suatu alat yang digunakan untuk membantu membuat program berjalan secara lebih baik untuk orang-orang yang ingin mereka layani. Dengan kata lain, evaluasi konteks, evaluasi input, evaluasi proses, dan evaluasi produk hanya merupakan bagian dari lingkungan evaluasi pada setiap institusi, dan fungsi yang paling penting dari studi yang dilakukan adalah dalam memenuhi 
kebutuhan marginal bagi adanya

informasi evaluative

Pengumpulan data bertujuan unuk mendeskripsikan keadaan sesungguhnya yang terjadi di lapangan, kemudian dibandingkan dengan standar pelaksanaan pelatihan sesuai dengan deskripsi teoritis. Adapun dalam penelitian ini, peneliti menggunakan tiga macam teknik pengumpulan data, yaitu observasi, wawancara mendalam, dan studi dokumenter.

Analisis data adalah proses mencari dan menyusun secara sistematis data yang diperoleh dari observasi, hasil wawancara, catatan lapangan, bahan-bahan lain, sehingga dapat mudah dipahami, dan temuannya dapat diinformasikan kepada orang lain.

Data yang telah teratur rapi melalui pengolahan dan penyederhanaan pada tahap selanjutnya perlu dianalisa yang pada gilirannya akan dapat menjadi acuan bagi penarikan kesimpulan. Setelah malakukan kegiatan pengumpulan data secara lengkap, maka tahap berikutnya adalah Analisa Data.

Untuk menjawab pertanyaan penelitian yang dikemukakan, maka teknis analisis data yang digunakan dalam penelitian ini adalah dengan metode analisis deskriptif kualitatif. Analisis ini terdiri dari tiga kegiatan, yaitu redaksi data, penyajian data, triangulasi, dan penarikan kesimpulan verifikasi.

\section{HASIL DAN PEMBAHASAN}

\section{A. Gambaran Objek Penelitian}

Pendirian Universitas Terbuka pada tahun 1984 yang dikukuhkan melalui Keppres Nomor 41 Tahun 1984. Dalam Keppres tersebut dinyatakan bahwa tujuan pendirian UT adalah dalam rangka memperbesar daya tampung Perguruan Tinggi sehingga sejauh mungkin mampu menjangkau calon mahasiswa di seluruh pelosok tanah air, perlu dilakukan cara dan pendekatan baru dengan memanfaatkan perkembangan teknologi yang telah ada. Tujuan lainnya adalah untuk memberikan manfaat yang lebih besar bagi pelaksanaan pembangunan dengan cara memberikan kesempatan kepada para tenaga terdidik untuk melanjutkan pendidikan tanpa harus meninggalkan pekerjaannya. Keppres tersebut juga menetapkan struktur UT yaitu Rektor; Pembantu Rektor; Biro Administrasi Akademik dan Kemahasiswaan; Biro Administrasi Umum; Fakultas Keguruan dan Ilmu Pendidikan; Fakultas Ekonomi; Fakultas Ilmu Sosial dan Ilmu Politik; Fakultas Matematika dan Ilmu Pengetahuan Alam; Pusat Penelitian dan Pengabdian pada Masyarakat; Pusat Produksi Media Pendidikan, Informatika dan Pengolahan Data, Pusat Pengujian; dan Unit Program Belajar Jarak Jauh.

Tugas pokok UT adalah menyelenggarakan pendidikan akademik dan profesional dalam sejumlah disiplin ilmu pengetahuan, teknologi, dan kesenian tertentu berdasarkan sistem jarak jauh. 


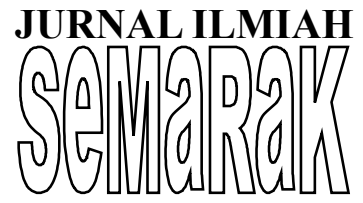

Dalam mendukung tugas pokok tersebut, fungsi-fungsi yang harus dimiliki UT adalah:

1. Melaksanakan dan mengembangkan pendidikan tinggi

2. Melaksanakan penelitian dalam rangka pengembangan ilmu pengetahuan, teknologi, dan atau kesenian

3. Melaksanakan pengabdian kepada masyarakat

4. Melaksanakan pembinaan sivitas akademika dan tenaga administrasi hubungannya dengan lingkungan

5. Melaksanakan kegiatan layanan administratif

\section{B. Penemuan dan Pembahasan}

Analisis data hasil penelitian tentang evaluasi program pelatihan desain pembelajaran bagi dosen Universitas Terbuka akan diungkapkan dalam bentuk deskriptif kualitatif dan kuantitatif yang diklasifikasikan berdasarkan komponen

konteks, komponen input, komponen proses, dan komponen produk. Semua komponen program tersebut member pengaruh terhadap keberhasilan tujuan program pelatihan.

\section{Evaluasi Konteks}

Hasil analisis data kuantitatif di atas dapat dirangkum bahwa 75\% sangat setuju bahwa tujuan program pelatihan ini sangat sesuai dengan kebutuhan unit (institusi) dan kebutuhan peserta pelatihan untuk meningkatkan kualitas pembelajaran khususnya kemampuan dalam mendesain bahan ajar atau modul Karena di UT memanfaatkan buku materi pokok untuk menyampaikan isi materi pembelajaran maka media tersebut harus didesain sebaik mungkin, berbeda dengan universitas konvensional lain dia memakai bahan ajar yang sudah ada di toko buku.

Hasil analisis data kualitatif komponen konteks dapat dirangkum bahwa pelatihan ini dipandang sesuai dengan kebijakan UT yaitu berdasarkan hasil analisis kebutuhan bahwa semua staf akademik (dosen) harus mempunyai kemampuan dasar dalam desain instruksional / pembelajaran, karena desain instruksional ini merupakan bisnis utama bagi UT dalam mendesain/membuat kurikulum, bahan ajar, dan evaluasi bahan ajar. UT itu berbeda dengan universitas konvensional atau perguruan tinggi lain. Universitas konvensional hanya tinggal menggunakan kurikulum dan bahan ajar yang sudah ada, sedangkan UT itu harus menyusun atau mendesain sendiri kurikulum dan membuat bahan ajar cetak serta evaluasi bahan ajarnya. Bahkan UT harus mampu membuat bahan ajar non cetak (BANC) untuk media pembelajarannya seperti video, audio, CD, dan lain sebagainya. Jadi secara kontekstual program ini memang sesuai dengan landasan dan tujuan pelatihan.

\section{Evaluasi Input}


Hasil analisis data kuantatif pada tabel di atas maka dapat dirangkum beberapa hal sebagai berikut. Input menurut peserta sudah memadai karena peserta sudah mempunyai pengetahuan awal tentang desain instruksional, instruktur mempunyai kualifikasi yang tinggi dalam mengajarkan materi pelatihan karena instrukturnya adalah pakar/ahli dalam bidang teknologi pendidikan memungkinkan peserta untuk menambah wawasan dan pengetahuan tentang desain instruksional. Sedangkan bahan pelatihan tersebut disusun secara sistematik dan relevan dengan isi program pelatihan sehingga membuat peserta lebih mudah dalam melaksanakan pelatihan.

Hasil data kualitatif dalam komponen input di atas dapat dirangkum bahwa tidak diperlukan kemampuan awal peserta untuk mengikuti program pelatihan desain pembelajaran, yang terpenting peserta tersebut harus mengenal struktur modul matakuliah ampuannya. Sedangkan motivasi peserta dalam mengikuti program pelatihan sangat tinggi untuk mengikuti program pelatihan ini, dikarenakan peserta mendapatkan banyak wawasan dan pengetahuan tentang desain instruksional yang baik dan benar. Untuk latar belakang calon peserta pelatihan, peserta tidak mempunyai latar belakang yang cukup, tapi dikarenakan mereka sudah bekerja lama di UT dari situlah mereka sudah mengetahui tentang desain instruksional. Sedangkan isi pembelajarannya sudah disusun secara sistematik berdasarkan prinsip desain instruksional yang diadopsi model pengembangan instruksional (MPI). Untuk masalah honorarium untuk instruktur belum memadai karena tidak sesuai dengan apa yang telah dikerjakan dari mulai pembuatan bahan pelatihan sampai proses pelatihan tersebut, karena prosesnya memakan waktu yang cukup lama.

\section{Evaluasi Proses}

Hasil analisis data kuantitatif di atas dapat disimpulkan bahwa komponen proses dinyatakan sesuai. Hal ini didukung dengan aktivitas dan fasilitas pembelajarannya dikelola secara baik sehingga membantu peserta belajar dengan nyaman. Instruktur menguraikan secara jelas konsepkonsep desain instruksional selama aktivitas pembelajaran sehingga membantu peserta dalam memahami isi pembelajaran tersebut dan instruktur merespon secara positif setiap pertanyaan yang diajukan peserta 


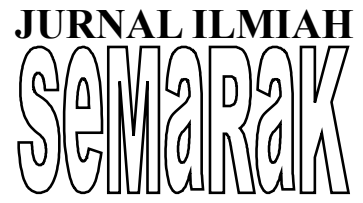

sehingga terjadi diskusi umum (tanya jawab). Tugas yang diberikan oleh instruktur tidak terlalu sulit sehingga mempermudah peserta menyelesaikan tugasnya. Dari segi waktu, waktunya cukup efektif yaitu $16 \mathrm{x}$ pertemuan (16 minggu) dikarenakan program ini setara dengan 3 sks program S3.

Hasil analisis data kualitatif tentang komponen proses dapat dirangkum bahwa prosesnya sudah berlangsung baik pelatihan ini meningkatkan kinerja dosen UT dalam menulis dan menelaah buku materi pokok. Pelatihan ini sudah berlangsung baik. Sedangkan proporsi teori dan praktek sudah cukup, teori boleh didapatkan dalam tatap muka (sesi pelatihan) tapi kalau prakteknya di luar itu dia harus mempraktekkannya, kalau prakteknya dilakukan pada jam pembelajaran waktunya tidak mungkin cukup. Ruangan pelatihan yang digunakan cukup memadai karena sudah disiapkan meja, kursi, LCD, dan ruangannya berAC jadi pesertanya merasa nyaman di dalam kelas. Untuk peraturan dalam pelatihan tersebut adalah bersifat umum misalnya datang harus tepat waktu, tidak meninggalkan kelas sebelum pelatihan berakhir, kemudian mengerjakan tugas akhir pelatihan (porto folio). Apabila peserta mengumpulkan tugas akhirnya tersebut mereka diberikan sertifikat, tetapi bagi mereka yang belum selesai membuat tugas mereka akan diberikan sertifikat telah berpartisipasi.

\section{Evaluasi Produk}

Hasil analisis data kuantitatif di atas dapat dirangkum bahwa komponen produk pelatihan sudah sesuai. Peserta pelatihan ingin mengaplikasikan program pelatihan ini dalam memperbaiki bahan ajar UT pada masa yang akan datang dan peserta terinspirasi untuk memperdalam materi desain pembelajaran serta yakin akan mampu menjadi pelatih desain pembelajaran bagi teman sejawat di UT

Hasil analisis data kualitatif tentang komponen produk di atas bahwa produk pelatihan sudah tercapai sesuai dengan tujuan program pelatihan. Porto folio atau produk akhir peserta setelah pelatihan sudah sangat memadai menurut prinsip-prinsip desain instruksional. Penilaian yang bersifat informal tidak diterapkan dipelatihan ini, jadi hanya diskusi umum saja, materi apa yang tidak dimengerti peserta boleh ditanyakan oleh instruktur. Kemudian Peserta pelatihan yakin pada akhir pelatihan ini dapat mengaplikasikan dalam memperbaiki bahan ajar UT sesuai dengan prosedur desain instruksional dan peserta mampu terinspirasi mempelajarinya. 


\section{KESIMPULAN DAN SARAN}

\section{A. Kesimpulan}

Berdasarkan atas hasil analisis evaluasi konteks, input, proses, dan produk maka dirumuskan beberapa kesimpulan penelitian sebagai berikut.

1. Efektivitas komponen konteks penyelenggaraan program pelatihan desain pembelajaran menyatakan bahwa $75 \%$ peserta pelatihan menyatakan sangat setuju bahwa tujuan program pelatihan desain pembelajaran ini relevan dengan keinginan peserta untuk mencapai kompetensi dalam mendesain ulang bahan ajar. $88 \%$ menyatakan sangat setuju bahwa program ini sesuai dengan upaya Universitas Terbuka untuk selalu meningkatkan kualitas bahan ajar. pelatihan ini dipandang sesuai dengan kebijakan UT yaitu berdasarkan hasil analisis kebutuhan bahwa semua staf akademik (dosen) harus mempunyai kemampuan dasar dalam desain instruksional/pembelajaran, karena desain instruksional ini merupakan bisnis utama bagi UT dalam mendesain/membuat kurikulum, bahan ajar, dan evaluasi bahan ajar. Jadi secara kontekstual program ini memang sesuai dengan tujuan dan landasan pelatihan.

2. Efektivitas komponen input $66 \%$ menyatakan setuju bahwa peserta memiliki pengetahuan awal yang memadai untuk mempelajari materi dalam program ini, $97 \%$ menyatakan sangat setuju bahwa instruktur mempunyai kualifikasi yang tinggi dalam mengajarkan materi pelatihan, dan bahan pelatihan disusun secara sistematik dan relevan dengan isi program pelatihan. Bebrapa aspek sudah memadai, namun masih ada aspek yang masih belum sejalan dan perlu disesuaikan adalah masalah honorarium untuk instruktur yang dipandang belum memadai dikarenakan sangat kecil. Hal ini tidak sesuai dengan apa yang dikerjakan dari penyusunan bahan pelatihan sampai dengan proses pelatihan.

3. Efektifitas komponen proses menunjukkan bahwa $47 \%$ menyatakan sangat setuju bahwa aktivitas belajar dalam program ini dikelola secara sistematik sehingga membantu peserta belajar secara bertahap proses. Sedangkan $50 \%$ menyatakan sangat setuju bahwa dukungan fasilitas pembelajaran program ini memenuhi kebutuhan peserta untuk belajar dengan nyaman. belajar mengajar yang dilakukan dalam pelatihan sesuai dengan kompetensi yang perlu dicapai oleh peserta pelatihan, hal ini didukung dengan aktivitas dan fasilitas pembelajarannya dikelola secara baik sehingga membantu peserta belajar dengan nyaman. Instruktur 
menguraikan secara jelas konsepkonsep desain instruksional selama aktivitas pembelajaran sehingga membantu peserta dalam memahami isi pembelajaran tersebut dan instruktur merespon secara positif setiap pertanyaan yang diajukan peserta sehingga terjadi diskusi umum (tanya jawab). Untuk peraturan dalam pelatihan tersebut adalah bersifat umum, apabila peserta mengumpulkan tugas akhirnya tersebut mereka akan diberikan sertifikat, tetapi bagi mereka yang belum selesai membuat tugas mereka akan diberikan sertifikat telah berpartisipasi. Jadi proses program pelatihan tersebut sudah sangat maksimal.

4. Efektivitas komponen produk pelatihan sudah tercapai sesuai dengan tujuan program pelatihan. 53\% menyatakan sangat setuju bahwa kompetensi yang telah dicapai pada akhir program ini dapat diaplikasikan dalam memperbaiki bahan ajar UT pada masa yang akan datang sesuai dengan prosedur desain instruksional. 28\% menyatakan sangat setuju bahwa peserta terinspirasi memperdalam materi desain pembelajaran ini. Secara keseluruhan pelatihan desain pembelajaran ini dinilai sudah cukup efektif dan dapat mencapai tujuan program pelatihan.

\section{B. Saran}

Berdasarkan kesimpulan, diajukan beberapa saran yang bersifat umum, yakni program pelatihan desain pembelajaran perlu dilanjutkan dengan memperhatikan hal-hal sebagai berikut.

1. Penyelenggaraan program pelatihan desain pembelajaran dipandang sudah tepat dan sejalan dengan visi dan misi Universitas Terbuka sehingga perlu diteruskan.

2. Pelatihan desain pembelajaran ini diwajibkan kepada seluruh dosen atau staf akademik yang berada di Universitas Terbuka. Kemampuan desain pembelajaran diperlukan oleh seluruh dosen UT, bukan hanya dosen fakultas keguruan dan ilmu pendidikan (FKIP) saja tetapi dosen fakultas ekonomi (FEKON), fakultas matematika dan ilmu pengetahuan alam (FMIPA), dan fakultas ilmu sosial dan ilmu politik (FISIP).

3. Produk peserta yang terbaik dan yang kurang baik dapat diarsipkan, sehingga peserta dapat membedakan mana produk yang baik dan yang kurang baik. Produk tersebut disimpan diruang arsip pusat pengembangan sumber daya manusia (PPSDM-UT).

4. Pelatihan ini menghasilkan produk berupa porto folio hasil karya peserta yang digunakan oleh peserta sebagai sarana pembelajaran. Peserta dapat 


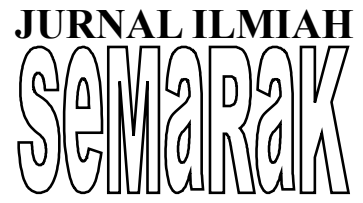

mempelajari komentar konstruktif dari instruktur.

\section{DAFTAR PUSTAKA}

Flippo, Edwin B. "Manajemen Personalia", Aksara Pratama, Jakarta, 2009.

Gomes, Faustino Cardoso. "Manajemen Sumber Daya Manusia", Yogyakarta, Andi Yogyakarta. 2003.

Handoko. T. Hani, "Manajemen Sumber Daya Manusia", Edisi ke 3, BPEF, Yogyakarta, 2009.

Handoko. T. Hani. "Manajemen" Edisike 2. BPFE, Yogyakarta: 2009.

Hasibuan, Malayu S.P. "Manajemen Sumber Daya Manusia", Jakarta, Bumi Aksara, 2009.

Iswanto, Yun. "Manajemen Sumber Daya Manusia", Jakarta, Universitas Terbuka, 2010.

Mangkunegara, A. A. Anwar Prabu. "Perencanaan dan Pengembangan Sumber Daya Manusia", Jakarta, Refika Aditama, 2005.

Moleong, Lexy J. "Metodologi Penelitian Kualitatif", Bandung, PT. Remaja Rosda Karya, 2013.

Pribadi, Benny A. "Model Desain Sistem Pembelajaran", Jakarta, Dian Rakyat, 2009.

Rivai, Veithzal. "Manajemen Sumber Daya Manusia untuk Perusahaan", PT. Raja Grapindo Persada, Jakarta, 2013.

Siagian, Sondang P. “Manajemen Sumber Daya Manusia", PT. Bumi Aksara, Jakarta, 2007.
Stufflebeam, D.L., dan Anthony J. Shinkfield. "Evaluation Theory, Models, \& Application" ${ }^{\text {st }}$ ed, San Francisco, Jossey-Bass, 2007.

Sukawati, Rina. "Evaluasi Program Pelatihan Pembuatan dan Pemanfaatan Media Sederhana Bagi Mahasiswa Universitas Negeri Jakarta", Tesis, 2010.

Suparman, Atwi. "Desain Instruksional Modern: Panduan Para Pengajar dan Inovator Pendidikan", Jakarta, Erlangga, 2012.

Tashakkori, Abbas dan Teddlie, Charles. "Mixed Methodology: Mengkombinasikan Pendekatan Kualitatif dan Kuantitatif", Jakarta, Pustaka Pelajar, 2010.

Terry, George R. "Prinsip-prinsip Manajemen", Jakarta, PT. Bumi Aksara, 2007. 